\title{
Effectiveness of Ultrasound Therapy in Cervical Myofascial Pain Syndrome: A Double Blind, Placebo- Controlled Study
}

\author{
Servikal Miyofasiyal Ağrı Sendromunda Ultrason Tedavisinin Etkinliği, \\ Çift Kör, Plasebo- Kontrollü Çalışma
}

\author{
Ümit Dündar, Özlem Solak, Fatma şamlı, Vural Kavuncu \\ Kocatepe Üniversitesi Tıp Fakültesi, Fiziksel Tıp ve Rehabilitasyon Anabilim Dalı, Afyonkarahisar, Turkey
}

\begin{abstract}
Objective: Ultrasound therapy is commonly employed in the treatment and management of soft tissue pain. The aim of this study was to investigate the effectiveness of ultrasound therapy in cervical myofascial pain syndrome (MPS).

Materials and Methods: A total of 55 patients with cervical MPS were included in this study. The patients were randomly assigned into two groups. In Group $1(n=28)$, ultrasound diathermy was administrated over three trigger points bilaterally for 8 minutes (min) once a day for 15 days over a period of three weeks. In Group $2(n=27)$, the same treatment protocol was given, but the ultrasound instrument was switched off during applications. All patients in both groups performed daily isometric exercise and stretching exercises for the cervical region. Parameters were measured at baseline, and at weeks 4 and 12. All patients were evaluated with respect to pain (at rest and movement) and assessed by visual analog scale and active range of motion was measured using an inclinometer and a goniometer. Disability and quality of life were evaluated with the Neck Disability Index (NDI) and the Nottingham Health Profile (NHP).

Results: In both groups, statistically significant improvements were detected in all outcome measures at weeks 4 and 12 (except sleep and social isolation subgroups of NHP in both groups) compared with baseline $(p<0.05)$. However, improvement in NDI and pain and physical abilities subgroups of NHP was better in Group 1. Pain reduction evaluated with respect to pain at rest and movement was also better in Group 1.

Conclusion: The results of our study showed that ultrasound therapy is effective in the management of cervical MPS.

(Turk J Rheumatol 2010; 25: 110-5)
\end{abstract}

Key words: Ultrasound, myofascial pain syndrome

Received: 24.09.2008

Accepted: 02.01.2009

\section{Özet}

Amaç: Ultrason tedavisi yumușak doku ağrısının tedavisinde sıklıkla uygulanmaktadır. Bu çalıșmanın amacı servikal miyofasiyal ağrı sendromunda (MAS) ultrason tedavisinin etkinliğini araștırmaktır.

Yöntem ve Gereçler: Çalıșmaya toplam 55 servikal MAS olan hasta dahil edildi. Hastalar rastgele iki tedavi grubuna ayrıldı. Birinci grupta $(n=28)$, ultrason diatermi bilateral her üç tetik noktayı kapsayacak șekilde 8 dakika süre ile günde bir kez olmak üzere üç haftalık periyotta toplam 15 seans verildi. İkinci grupta $(n=27)$, aynı tedavi protokolü uygulandı fakat, uygulama sırasında cihaz kapatıldı. Her iki gruptaki bütün hastalar servikal bölge için günlük izometrik ve germe egzersizleri uyguladılar. Değerlendirme parametreleri çalıșmanın bașlangıcında, 4. hafta ve 12. haftada ölçüldü. Bütün hastalar görsel anolog skala ile istirahat ve hareket ağrısı açısından değerlendirildi. Aktif hareket açıklığı inklinometre ve gonyometre ile ölçüldü. Disabilite ve yașam kalitesi ise boyun disabilite indeksi (BDi) ve Nottingham sağlık profili (NSP) ile değerlendirildi.

Bulgular: Her iki grupta 4. ve 12. hafta sonunda bașlangıca göre tüm parametrelerde (her iki grupta NSP'nin uyku ve sosyal izolasyon alt parçaları hariç) istatistiksel olarak anlamlı iyileșmeler saptandı $(p<0.05)$. Bununla beraber BDi ve NSP'nin ağrı ve fizisel yetenekler alt parçalarındaki iyileșmeler birinci grupta daha iyiydi. Ayrıca istirahatte ve harekette değerlendirlen ağrı azalması da birinci grupta daha iyi bulundu.

Sonuç: Sonuç olarak çalıșmamızın sonuçları servikal MAS'nun tedavisinde ultrason tedavisinin etkiliği olduğunu göstermiștir. (Turk J Rheumatol 2010; 25: 110-5)

Anahtar sözcükler: Ultrason, miyofasiyal ağrı sendromu

Alındığı Tarih: 24.09.2008 Kabul Tarihi: 02.01.2009 


\section{Introduction}

Myofascial pain syndrome (MPS) is a soft tissue rheumatism or a regional pain syndrome characterized by the presence of trigger points in muscle and/or fascial bands and development of pain, sensory changes and local twitch response reflected by stimulation of these points (1).

In most cases, due to a stiff trapezius muscle, neck and upper back pain is the most common complaint in MPS. The prevalence of this syndrome has increased dramatically in recent years and is foremost among the causes of musculoskeletal pain. The aim in the treatment of MPS is to inactivate the trigger point and loosen the tight muscle bands. The goal is to reach normal muscle length, function and power by decreasing the muscle tension $(2,3)$.

Myofascial pain syndrome treatment is difficult and results may not always be satisfying. Physical therapy modalities are applied as well as various treatment approaches. The main treatment methods include patient education, stretching exercises, medical treatment, local injection, ultrasound (US), massage, electrotherapy, acupuncture methods, and ischemic compression (4).

Thermal and non-thermal effect occurs in tissue during the US treatment by using high-frequency acoustic energy. During the absorption of ultrasonic waves in tissues and their reflection among the surfaces, heat energy is produced and provides deep heating. It has been found from US studies that US causes a significant increase in the intraarticular temperature. At the same time, US therapy has analgesic effects, increases nutrition and also speeds blood circulation. In addition, the micro-massage effects of high-frequency sound waves have been demonstrated (5). However, placebo-controlled double-blind studies evaluating the efficacy of US are rather limited.

The purpose of this study was to investigate the efficacy of US treatment in patients with cervical MPS.

\section{Materials and Methods}

This study included 55 patients with the diagnosis of cervical MPS (mean age: $36.2 \pm 12.2$ years). Patients with pathological findings in routine blood tests (complete blood count, serum glucose, renal and liver function tests, calcium, phosphorus, alkaline phosphatase, erythrocyte sedimentation rate, C-reactive protein) or on cervical X-ray radiographs were excluded from the study. Patients who had received physical therapy and trigger point injections within the previous six months were also excluded. MPS diagnosis was made according to Simons criteria, which include five major and three minor criteria (6).

Major criteria:

1. Regional pain complaint in the neck.

2. Pain complaint or altered sensation in the expected distribution of referred pain from a myofascial trigger point.
3. Taut band palpable in an accessible muscle.

4. Excruciating spot tenderness at one point along the length of the taut band.

5. Some degree of restricted range of motion (ROM), when measurable.

Minor criteria:

1. Reproduction of clinical pain complaint, or altered sensation, by pressure on the tender spot.

2. Elicitation of a local twitch response by transverse snapping palpation at the tender spot or by needle insertion into the tender spot in the taut band.

3. Pain alleviated by elongating (stretching) the muscle or by injecting the tender spot (trigger point).

Cervical MPS was diagnosed with five major criteria and at least one minor criterion. All the patients included in the study were asked not to take any analgesic medication during the follow-up. Patients were divided randomly into two treatment groups. Random sampling method was performed using numbered envelopes.

Ultrasound (US) treatment was performed with EnrafNonius Sonopuls 590 device. In Group $1(n=28)$, US was performed every three trigger points bilaterally to cover the trapezius muscle over 8 minutes (mins) (1.5 watt $/ \mathrm{cm}^{2}$ dose, $1 \mathrm{MHz}$ frequency, continuous mode US) during a session every day, for a total of 15 sessions (in a 3-week period). In Group 2 ( $n=27)$, the same treatment protocol was given, but the US instrument was switched off during applications. All patients in both groups performed daily isometric exercise and stretching exercises for the cervical region under the supervision of the physiotherapist. All US applications were carried out by the same physiotherapist.

One of the doctors evaluated the clinical parameters before the initiation of treatment. After the treatment, results were evaluated by the other doctors. All physicians were blinded to the treatment. Only physiotherapists (not included in the study) knew the treatment and applied this treatment to the patient. Evaluation parameters were measured at the beginning of the study and after 4 and 12 weeks.

Pain at rest and at movement was evaluated with visual analog scale (VAS). Joint ROM measurements were performed using inclinometer and goniometer (cervical flexion-extension, lateral flexion and rotation). Neck Disability Index (NDI) was used to measure changes in functional disability. Quality of life was measured with Nottingham Health Profile (NHP).

The NHP consists of two parts, but only the first part was utilized in this study. The first part includes six fields (pain, physical abilities, emotional reactions, energy, social isolation and sleep) and 38 yes/no questions. NHP scores range from zero (no problem) to 100 (presence of all the problems in an area). The NHP Turkish version was used in this study (7). 
The NDI consists of 10 items and each item is scored between $0-5$. The maximum score is 50 . The obtained score can be multiplied by 2 to produce a percentage score. The obtained score was also multiplied by 2 in this study (8).

Informed consent was obtained before the examination and the study received approval from the local ethics committees of the Kocatepe University.

\section{Statistical Analysis}

A value of $p<0.05$ was considered significant for the study. The average percentage changes in values of both groups were compared using the Mann-Whitney $U$ test. Paired t-test was used for comparison of values within groups before and after treatment. The chi-square test and Fisher's exact test were used for comparison of categorical variables. All analyses were performed using the SPSS 13.0 for Windows.

\section{Results}

All patients completed the study, and no side effects were observed. There were no statistically significant differences in pre-treatment parameters between the groups. Demographic characteristics and pre-treatment evaluation parameters are shown in Table 1.

Significant improvements were observed in all parameters in both groups (except for NHP sleep and social isolation subgroups) at the end of the 4th and 12th weeks (Tables 2, 3).

However, improvement (percentage changes) in NDI and pain and physical abilities subgroups of NHP was better in Group 1. Pain reduction evaluated with respect to pain at rest and movement was also better in Group 1. With respect to percentage changes of the other parameters, no significant difference was found between the two groups (Table 4).

\section{Discussion}

The use of US therapy in the treatment of musculoskeletal disorders is not new. While US therapy has been used for the treatment of pain and disability for many years, the number of placebo-controlled doubleblind studies showing the effectiveness of US treatment is negligible. Furthermore, contradictory results have been reported in some of the existing studies. US therapy in both periarticular calcific tendinitis and in the presence of inflammation has been shown to be beneficial in the analysis of two compilations in the literature $(9,10)$. In other compilations ( 2 related to the use of US in osteoarthritis, 1 regarding use of US in patellofemoral pain), US treatment has been reported to be ineffective (11-13). In this review, the literature was searched for studies of US treatment, and most of the current studies indicated its low quality. However, some recent studies showed that US therapy could be used in the inactivation of trigger points in MPS. In two placebo-controlled studies, Srbely and colleagues $(14,15)$ showed that low doses of US treatment increased pain pressure threshold and reduced sensitivity on the trigger point by creating short-term antinociceptive effects on trigger points. The most important limitation of these studies is that followup included only the first 15-minute period after US

\begin{tabular}{|c|c|c|c|}
\hline & $\begin{array}{c}\text { Placebo Group } \\
(m e a n \pm S D)(n=28)\end{array}$ & $\begin{array}{c}\text { Placebo Group } \\
(m e a n \pm S D)(n=27)\end{array}$ & $p$ \\
\hline Age (year) & $36.6 \pm 11.9$ & $35.8 \pm 12.5$ & 0.527 \\
\hline Sex (F/M) & $20 / 8$ & $19 / 8$ & 0.892 \\
\hline Pain at rest (VAS) (cm) & $4.7 \pm 2.4$ & $4.8 \pm 2.6$ & 0.920 \\
\hline Pain at movement (VAS) $(\mathrm{cm})$ & $6.3 \pm 2.9$ & $6.1 \pm 2.4$ & 0.654 \\
\hline Flexion $\left({ }^{\circ}\right)$ & $57.7 \pm 11.2$ & $58.2 \pm 10.9$ & 0.681 \\
\hline Extension $\left({ }^{\circ}\right)$ & $58.2 \pm 10.1$ & $59.4 \pm 9.3$ & 0.423 \\
\hline Right lateral flexion $\left({ }^{\circ}\right)$ & $41.3 \pm 6.7$ & $41.9 \pm 6.1$ & 0.775 \\
\hline Left lateral flexion $\left({ }^{\circ}\right)$ & $41.9 \pm 6.2$ & $42.6 \pm 6.9$ & 0.812 \\
\hline Right rotation $\left({ }^{\circ}\right)$ & $75.3 \pm 9.3$ & $74.2 \pm 8.9$ & 0.698 \\
\hline Left rotation $\left(^{\circ}\right)$ & $74.9 \pm 8.6$ & $76.3 \pm 9.4$ & 0.524 \\
\hline NDI & $32.1 \pm 11.4$ & $31.5 \pm 12.1$ & 0.769 \\
\hline NHP Physical abilities & $23.5 \pm 11.9$ & $23.9 \pm 11.8$ & 0.676 \\
\hline NHP Pain & $59.2 \pm 26.7$ & $57.7 \pm 29.3$ & 0.521 \\
\hline NHP Level of energy & $41.9 \pm 22.7$ & $42.6 \pm 24.4$ & 0.723 \\
\hline NHP Emotional reactions & $25.4 \pm 15.1$ & $26.6 \pm 19.3$ & 0.611 \\
\hline NHP Sleep & $36.7 \pm 26.3$ & $39.3 \pm 24.7$ & 0.342 \\
\hline NHP Social isolation & $10.3 \pm 9.1$ & $11.6 \pm 10.6$ & 0.425 \\
\hline
\end{tabular}

VAS: Visual analog scale, F: Female, M: Male, ${ }^{\circ}$ Degree, NDI: Neck Disability Index, NHP: Nottingham Health Profile

Values show mean \pm SD 


\begin{tabular}{|c|c|c|c|c|c|}
\hline & $\begin{array}{l}\text { Baseline } \\
\text { (Week 0) }\end{array}$ & Week 4 & Week 12 & $\begin{array}{c}\text { P } \\
\text { (Baseline-Week 4) }\end{array}$ & $\begin{array}{c}P \\
\text { (Baseline-Week 12) }\end{array}$ \\
\hline Pain at rest (VAS) $(\mathrm{cm})$ & $4.7 \pm 2.4$ & $3.1 \pm 1.9$ & $2.9 \pm 2.1$ & $<0.001$ & $<0.001$ \\
\hline Pain at movement (VAS) $(\mathrm{cm})$ & $6.3 \pm 2.9$ & $3.9 \pm 2.2$ & $3.7 \pm 2.1$ & $<0.001$ & $<0.001$ \\
\hline Flexion $\left({ }^{\circ}\right)$ & $57.7 \pm 11.2$ & $64.3 \pm 10.9$ & $66.2 \pm 10.8$ & 0.001 & $<0.001$ \\
\hline Extension $\left({ }^{\circ}\right)$ & $58.2 \pm 10.1$ & $66.3 \pm 11.2$ & $68.1 \pm 10.8$ & $<0.001$ & $<0.001$ \\
\hline Right lateral flexion $\left({ }^{\circ}\right)$ & $41.3 \pm 6.7$ & $42.7 \pm 6.4$ & $42.9 \pm 6.2$ & 0.005 & 0.004 \\
\hline Left lateral flexion $\left(^{\circ}\right)$ & $41.9 \pm 6.2$ & $43.2 \pm 6.4$ & $43.4 \pm 6.3$ & 0.008 & 0.007 \\
\hline Right rotation $\left({ }^{\circ}\right)$ & $75.3 \pm 9.3$ & $78.8 \pm 10.4$ & $79.5 \pm 9.9$ & 0.001 & $<0.001$ \\
\hline Left rotation $\left({ }^{\circ}\right)$ & $74.9 \pm 8.6$ & $79.1 \pm 9.8$ & $79.9 \pm 9.7$ & 0.002 & $<0.001$ \\
\hline NDI & $32.1 \pm 11.4$ & $17.4 \pm 9.1$ & $16.3 \pm 8.6$ & $<0.001$ & $<0.001$ \\
\hline NHP Physical abilities & $23.5 \pm 11.9$ & $10.9 \pm 8.3$ & $9.8 \pm 8.6$ & $<0.001$ & $<0.001$ \\
\hline NHP Pain & $59.2 \pm 26.7$ & $32.5 \pm 14.8$ & $29.7 \pm 13.9$ & $<0.001$ & $<0.001$ \\
\hline NHP Level of energy & $41.9 \pm 22.7$ & $23.4 \pm 15.3$ & $21.5 \pm 15.7$ & $<0.001$ & $<0.001$ \\
\hline NHP Emotional reactions & $25.4 \pm 15.1$ & $15.8 \pm 9.7$ & $13.7 \pm 9.2$ & 0.001 & $<0.001$ \\
\hline NHP Sleep & $36.7 \pm 26.3$ & $31.8 \pm 21.9$ & $32.5 \pm 24.5$ & 0.152 & 0.169 \\
\hline NHP Social isolation & $10.3 \pm 9.1$ & $9.5 \pm 8.7$ & $9.7 \pm 9.2$ & 0.427 & 0.532 \\
\hline
\end{tabular}

Table 3. Comparison of the pretreatment (week 0) and post-treatment (week 4 and week 12) evaluation parameters in the placebo group $(n=27)$

\begin{tabular}{|c|c|c|c|c|c|}
\hline & $\begin{array}{l}\text { Baseline } \\
\text { (Week 0) }\end{array}$ & Week 4 & Week 12 & $\begin{array}{c}\text { P } \\
\text { (Baseline-Week 4) }\end{array}$ & $\begin{array}{c}\text { P } \\
\text { (Baseline-Week 12) }\end{array}$ \\
\hline Pain at rest (VAS) (cm) & $4.8 \pm 2.6$ & $3.6 \pm 1.8$ & $3.4 \pm 1.9$ & $<0.001$ & $<0.001$ \\
\hline Pain at movement (VAS) $(\mathrm{cm})$ & $6.1 \pm 2.4$ & $4.4 \pm 1.9$ & $4.2 \pm 2.1$ & $<0.001$ & $<0.001$ \\
\hline Flexion $\left({ }^{\circ}\right)$ & $58.2 \pm 10.9$ & $65.6 \pm 10.7$ & $67.9 \pm 10.8$ & $<0.001$ & $<0.001$ \\
\hline Extension $\left({ }^{\circ}\right)$ & $59.4 \pm 9.3$ & $67.1 \pm 10.2$ & $69.5 \pm 10.7$ & $<0.001$ & $<0.001$ \\
\hline Right lateral flexion $\left({ }^{\circ}\right)$ & $41.9 \pm 6.1$ & $43.1 \pm 6.4$ & $43.4 \pm 6.5$ & 0.006 & 0.005 \\
\hline Left lateral flexion $\left({ }^{\circ}\right)$ & $42.6 \pm 6.9$ & $44.1 \pm 6.2$ & $44.3 \pm 6.7$ & 0.005 & 0.004 \\
\hline Right rotation $\left({ }^{\circ}\right)$ & $74.2 \pm 8.9$ & $78.6 \pm 10.3$ & $79.4 \pm 9.5$ & $<0.001$ & $<0.001$ \\
\hline Left rotation $\left(^{\circ}\right)$ & $76.3 \pm 9.4$ & $79.4 \pm 9.8$ & $80.2 \pm 9.9$ & 0.005 & 0.001 \\
\hline NDI & $31.5 \pm 12.1$ & $22.9 \pm 10.3$ & $20.8 \pm 9.8$ & $<0.001$ & $<0.001$ \\
\hline NHP Physical abilities & $23.9 \pm 11.8$ & $15.1 \pm 10.1$ & $14.2 \pm 9.6$ & 0.001 & $<0.001$ \\
\hline NHP Pain & $57.7 \pm 29.3$ & $43.2 \pm 18.1$ & $39.6 \pm 16.6$ & $<0.001$ & $<0.001$ \\
\hline NHP Level of energy & $42.6 \pm 24.4$ & $22.2 \pm 14.3$ & $20.3 \pm 16.7$ & $<0.001$ & $<0.001$ \\
\hline NHP Emotional reactions & $26.6 \pm 19.3$ & $16.4 \pm 9.5$ & $13.9 \pm 9.8$ & $<0.001$ & $<0.001$ \\
\hline NHP Sleep & $39.3 \pm 24.7$ & $34.2 \pm 20.3$ & $33.9 \pm 21.2$ & 0.144 & 0.133 \\
\hline NHP Social isolation & $11.6 \pm 10.6$ & $10.7 \pm 9.9$ & $10.4 \pm 9.8$ & 0.409 & 0.395 \\
\hline
\end{tabular}

treatment in the trigger points, and there was no information about the long-term results. In another doubleblind placebo-controlled study, Majlesi and colleagues (16) reported that high-power US therapy was more successful compared to conventional US therapy in the treatment of trigger points in MPS, and the treatment period was significantly shortened. However, Gam and colleagues (17) performed another study regarding US in the treatment of trigger points in MPS in two groups (massage and exercise therapy with placebo US and massage and exercise therapy with US), and a statistical difference was found between the groups in the evaluation parameters. In our study comparing the US treatment group and a placebo US group, statistically significant improvements were identified with US treatment in the majority of the evaluation parameters (pain at movement and at rest, NDI and NHP pain and physical capabilities subgroups), and improvements were sustained up to the end of the third month. 
Table 4. Comparison of the two groups on the basis of the post-treatment (week 4 and week 12) percentage changes and difference in scores relative to pre-treatment (week 0 ) values

\begin{tabular}{lcccccc}
\hline & $\begin{array}{c}\text { 4th Week } \\
\text { Group 1 } \\
\text { (Ultrasound) }\end{array}$ & $\begin{array}{c}\text { Group 2 } \\
\text { (Placebo) }\end{array}$ & $\mathbf{P}$ & $\begin{array}{c}\text { 12th Week } \\
\text { Group 1 } \\
\text { (Ultrasound) }\end{array}$ & $\begin{array}{c}\text { Group } \\
\text { (Placebo) }\end{array}$ \\
\hline Pain at rest (VAS) (cm) & $-0.34 \pm 0.10$ & $-0.25 \pm 0.16$ & $<0.001$ & $-0.38 \pm 0.09$ & $-0.31 \pm 0.14$ & $\mathbf{0 . 0 0 1}$ \\
Pain at movement (VAS) (cm) & $-0.38 \pm 0.11$ & $-0.28 \pm 0.08$ & $<0.001$ & $-0.41 \pm 0.12$ & $-0.31 \pm 0.05$ & $<0.001$ \\
Flexion $\left(^{\circ}\right.$ ) & $0.11 \pm 0.01$ & $0.12 \pm 0.01$ & NS & $0.14 \pm 0.01$ & $0.16 \pm 0.01$ & NS \\
Extension $\left(^{\circ}\right.$ ) & $0.14 \pm 0.02$ & $0.13 \pm 0.02$ & NS & $0.17 \pm 0.01$ & $0.17 \pm 0.02$ & NS \\
Right lateral flexion $\left(^{\circ}\right)$ & $0.03 \pm 0.01$ & $0.03 \pm 0.01$ & NS & $0.04 \pm 0.01$ & $0.04 \pm 0.01$ & NS \\
Left lateral flexion $\left(^{\circ}\right)$ & $0.03 \pm 0.01$ & $0.04 \pm 0.02$ & NS & $0.04 \pm 0.01$ & $0.04 \pm 0.01$ & NS \\
Right rotation $\left(^{\circ}\right)$ & $0.05 \pm 0.01$ & $0.06 \pm 0.02$ & NS & $0.06 \pm 0.01$ & $0.07 \pm 0.01$ & NS \\
Left rotation $\left(^{\circ}\right)$ & $0.06 \pm 0.02$ & $0.04 \pm 0.01$ & NS & $0.07 \pm 0.02$ & $0.05 \pm 0.02$ & NS \\
NDI & $-0.46 \pm 0.07$ & $-0.27 \pm 0.06$ & $<0.001$ & $-0.49 \pm 0.09$ & $-0.34 \pm 0.07$ & $<0.001$ \\
NHP Physical abilities & $-0.53 \pm 0.15$ & $-0.37 \pm 0.07$ & $<0.001$ & $-0.58 \pm 0.14$ & $-0.40 \pm 0.09$ & $<0.001$ \\
NHP Pain & $-0.45 \pm 0.20$ & $-0.25 \pm 0.19$ & $<0.001$ & $-0.50 \pm 0.21$ & $-0.31 \pm 0.22$ & $<0.001$ \\
NHP Level of energy & $-0.44 \pm 0.17$ & $-0.47 \pm 0.23$ & NS & $-0.49 \pm 0.16$ & $-0.52 \pm 0.18$ & NS \\
NHP Emotional reactions & $-0.38 \pm 0.21$ & $-0.38 \pm 0.35$ & NS & $-0.46 \pm 0.23$ & $-0.48 \pm 0.36$ & NS \\
NHP Sleep & $-0.13 \pm 0.12$ & $-0.13 \pm 0.11$ & NS & $-0.11 \pm 0.05$ & $-0.14 \pm 0.09$ & NS \\
NHP Social isolation & $-0.08 \pm 0.04$ & $-0.08 \pm 0.06$ & NS & $-0.06 \pm 0.01$ & $-0.09 \pm 0.07$ & NS \\
\hline
\end{tabular}

VAS: Visual analog scale, ${ }^{\circ}$ : Degree, NDI: Neck Disability Index, NHP: Nottingham Health Profile, NS: Non significant Values show mean \pm SD

Some theories on the effectiveness of US treatment in pain control in MPS have been suggested, including: increased blood flow depending on the pain-causing mediators to be removed from the environment (18), nerve conduction changes or cell membrane permeability changes depending on the reduction in inflammation (19), increased capillary density in muscle tissue (20), energy consumption improvement in the cell (21), increased angiogenesis in ischemic tissue (22), and acceleration of the healing of tissue and improved persistent muscle spasm (23). In addition to these mechanisms, stimulation of somatosensory receptors within the trigger points may reduce regional pain sensation, which in turn may decrease the sensitivity of trigger points or even result in their resolution by means of relaxation in tight bands.

In our study, the placebo group had significant improvements in all parameters (except for NHP sleep and social isolation subgroups) as well. Stretching exercise forms the basis of treatment in MPS and diminishes pain by reducing muscle tension, restoring muscle length and deactivating trigger points (24). Significant improvements observed in both the patients with placebo and the US treatment group could be explained by the effectiveness of the daily stretching exercises and isometric exercise.

The most important limitation of our study is the minimal number of patients in the study group. The US treatment group also did not include different doses and frequency, which reduces the power of the statistical evaluation.
In conclusion, our double-blind placebo-controlled study showed significant improvements in pain, disability and quality of life parameters in MPS with US therapy. New studies are needed regarding the efficacy of US treatment in MPS that include a greater number of patients, and different doses, duration and frequency of US treatment.

\section{Conflict of Interest}

No conflict of interest is declared by authors.

\section{References}

1. Fricton JR. Myofascial pain syndrome: characteristics and epidemiology. In: Fricton JR, Award EA (eds). Advances in Pain Research and Therapy. New York: Raven Press, 1990: 107-24.

2. Borg-Stein J, Simons DG. Myofascial pain. Arch Phys Med Rehabil 2002; 83: 40-9.

3. Wheeler AH. Myofascial pain disorders: theory to therapy. Drugs 2004; 64: 45-62.

4. Fricton JR. Management of myofascial pain syndromes In: Friction JR, Award EA (eds). Advances in Pain Research and Therapy. New York: Raven Press, 1990: 325-46.

5. Tuncer T. Elektroterapi. In: Beyazova M, Kutsal YG (eds). Fiziksel Tıp ve Rehabilitasyon. Cilt 1. Ankara: Güneș Kitabevi, 2000: 771-89.

6. Simons DG. Muscular pain syndrome. In: Friction JR, Award EA (eds). Advances in Pain Research and Therapy. New York: Raven Press, 1990: 1-41.

7. Kucukdeveci AA, McKenna SP, Kutlay S, Gursel Y, Whalley D, Arasil T. The development and psychometric assessment of 
the Turkish version of the Nottingham Health Profile. Int J Rehabil 2000; 23: 31-8.

8. Vernon H, Mior S. The Neck Disability Index: a study of reliability and validity. J Manipulative Physiol Ther 1991; 14: 409-15.

9. Falconer J, Hayes KW, Chang RW. Therapeutic ultrasound in the treatment of musculoskeletal conditions. Arthritis Care Res 1990; 3: 85-91.

10. Philadelphia Panel. Philadelphia panel evidence-based clinical practice guidelines on selected rehabilitation interventions for knee pain. Phys Ther 2001; 81: 1675-700.

11. Puett DW, Griffin MR. Published trials of nonmedicinal and noninvasive therapies for hip and knee osteoarthritis. Ann Intern Med 1994; 121: 133-40.

12. Welch V, Brosseau L, Peterson J, Shea B, Tugwell P, Wells G. Therapeutic ultrasound for osteoarthritis of the knee. Cochrane Database Syst Rev 2001: CD003132.

13. Brosseau L, Casimiro L, Robinson V, Milne S, Shea B, Judd M, et al. Therapeutic ultrasound for treating patellofemoral pain syndrome. Cochrane Database Syst Rev. 2001.

14. Srbely JZ, Dickey JP, Lowerison M, Edwards AM, Nolet PS, Wong LL. Stimulation of myofascial trigger points with ultrasound induces segmental antinociceptive effects: a randomized controlled study. Pain 2008; 139: 260-6.

15. Srbely JZ, Dickey JP. Randomized controlled study of the antinociceptive effect of ultrasound on trigger point sensitivity: novel applications in myofascial therapy? Clin Rehabil 2007; 21: 411-7.
16. Majlesi J, Unalan H. High-power pain threshold ultrasound technique in the treatment of active myofascial trigger points: a randomized, double-blind, case-control study. Arch Phys Med Rehabil 2004; 85: 833-6.

17. Gam AN, Warming $S$, Larsen LH, Jensen B, Høydalsmo $O$ Allon I, et al. Treatment of myofascial trigger-points with ultrasound combined with massage and exercise-a randomised controlled trial. Pain 1998; 77: 73-9.

18. Esposito CJ, Veal SJ, Farman AG. Alleviation of myofascial pain with ultrasonic therapy. J Prosthet Dent 1984; 51: 106-8.

19. Watson T. The role of electrotherapy in contemporary physiotherapy practice. Man Ther 2000; 5: 132-41.

20. Hogan RD, Burke KM, Franklin TD. The effect of ultrasound on microvascular hemodynamics in skeletal muscles: effects during ischemia. Microvasc Res 1982; 23: 370-9.

21. Montes Molina R, Martin Garcia MS, Gonzales Mayoral ML. Effect of muscular ultrasound stimulation on power spectrum electromyography during a strengthening training. Electromyogr Clin Neurophysiol 2000; 40: 163-8.

22. Fabrizio PA, Schmidt JA, Clemente FR, Lankiewicz LA, Levine ZA. Acute effects of therapeutic ultrasound delivered at varying parameters on the blood flow velocity in a muscular distribution artery. J Orthop Sports Phys Ther 1996; 24: 294-302.

23. Guerino MR, Luciano E, Goncalves M, Leivas TP. Effects of chronic physical activity and ultrasound treatment on bone consolidation. Physiol Chem Phys Med NMR 1999; 31: 131-8.

24. Gerwin RD. A review of myofascial pain and fibromyalgia factors that promote their persistence. Acupunct Med 2005; 23(3): 121-34. 